\title{
Endothelial cells as cytotoxic effector cells: cytokine-activated rat islet endothelial cells lyse syngeneic islet cells via nitric oxide
}

\author{
L.Steiner, K.-D.K röncke, K. Fehsel, V. Kolb-B achofen \\ R esearch G roup I mmunobiology in the B iomedical R esearch Centre, H einrich-H eine-U niversity, D üsseldorf, G ermany
}

Summary In vivo, each beta cell is located in proximity to at least one capillary islet endothelial cell. R at aorta and islet endothelial cells can be activated in vitro to express inducible nitric oxide synthase by a cytokine mixture of tumour necrosis factor- $\alpha$, gamma-interferon, and interleukin- $1 \beta$ and to produce high concentrations of nitric oxide. We have performed co-culture experiments with rat islet endothelial cells together with isolated syngeneic islet cells at low target : effector ratios with or without previous cytokine challenge of endothelial cultures. Co-cultures were al ways free of exogenous cytokines, which were removed prior to addition of islet cells. We found that pre-activated, in contrast to resident islet endothelial cells, at a target: effector ratio as low as 1:1 almost completely lysed syngeneic beta and non-beta cells within $24 \mathrm{~h}$ of co-culture. Lysis by pre-activated islet endothelial cells was found to be preceded by DNA damage found in $46 \%$ of islet cells after $8 \mathrm{~h}$ of co-culture with pre-activated vs $7 \%$ with resting islet endothelial cells. Lysis was blocked to control levels in the presence of the nitric oxide synthase inhibitor $\mathrm{N}^{\mathrm{G}}$-methyl-L-arginine. With the results presented here, we demonstrate for the first time, that activated endothelial lining cells can express effector cell activity and thus can contribute to local tissue destruction, especially in organs that are densely capillarized such as pancreatic islets. [Diabetologia (1997) 40: 150-155]

Keywords Cytotoxicity, diabetes mellitus, endothelia, nitric oxide.
E ndothelial cells (EC) have long been considered to be only a mechanical barrier of blood vessels. However, evidence is accumulating for a decisive role of EC in immune responses [1]. U pon exposure to local signals such as cytokines, EC undergo profound alterations in gene expression and cell function. Thus, activated EC participate in leukocyte recruitment by producing chemoattractants, by regulated expression

R eceived: 2 September 1996 and in revised form: 240 ctober 1996

Corresponding author: Dr. K.-D.K röncke, R esearch Group I mmunobiology 14.80, M E D-H einrich-H eine-U niversity, P. O. B ox 101007, D-40001 D üsseldorf, G ermany

A bbreviations: IE C, I slet endothelial cells; iNOS, inducible nitric oxide synthase; NMA, N ${ }^{G}$-methyl-L-arginine; ECGS, endothelial cell growth supplement; TNF $-\alpha$, tumour necrosis factor alpha; PBS, phosphate buffered saline; N O, nitric oxide of adhesion molecules and also by modulating local blood flow. In addition, endothelial expression of M H C class II molecules as well as production of cytokines (interleukins: IL - I, I L-6, IL-8) [1], oxygen radicals $[2,3]$ and/or high concentrations of nitric oxide (NO) [4-6] may actively participate in local inflammatory reactions. Specific NO synthase inhibitors partially suppress or delay insulin-dependent diabetes mellitus (ID D M ) in animal models [7-10] suggesting that in vivo $\mathrm{NO}$ contributes to the development of IDDM presumably released by activated macrophages infiltrating the pancreatic islets of $L$ angerhans early during development of ID D M in animal models [11-13]. Indeed, in vitro experiments showed lysis of syngeneic islet cells mediated by activated macrophages via NO [14]. H owever, constitutive cell populations of isl ets also bear the potential for inducible nitric oxide synthase (iN O S) expression and high output NO synthesis, namely the capillary islet endothelial 
cell (IEC), as has been shown previously [6]. In vivo each insulin-producing beta cell is located in close proximity to at least one capillary IEC, which thus could potentially contribute to destructive processes. We established a co-culture system of pure rat IE C with syngeneic isolated islet cells and showed for the first time, that the capillary-lining cells are capable of becoming immune effector cells in an inflammatory surrounding and thus must be considered as possible contributors to tissue breakdown preceding autoimmune diabetes.

\section{Materials and methods}

M aterials. $N^{G}$-methyl-L-arginine acetate salt (NMA), sulphanilamide, naphtylethylendiamine, collagenase from Clostridium histolyticum and EC growth supplement (ECGS) were purchased from Sigma (D eisenhofen, G ermany), recombinant human tumour necrosis factor- $\alpha$ (TNF- $\alpha$ ) and interleukin- $1 \beta$ (IL-1 $\beta$ ) from Pharma Biotechnologie Hannover (Hannover, Germany) and recombinant rat gamma-interferon (gammaIFN) from $\mathrm{H}$ yCult Biotechnology (L eiden, The $\mathrm{N}$ etherlands). A II cells were cultured in R PM I 1640 (pH 7.2) without nitrate containing $4 \mathrm{mmol} / \mathrm{l}$ glucose and supplemented with $6 \times$ $10^{4} \mathrm{U} / /$ penicillin, $60 \mathrm{mg} / \mathrm{l}$ streptomycin, $1 \mathrm{mmol} / \mathrm{l}$ sodium pyruvate, $2 \mathrm{mmol} / /$ glutamine, $10 \mathrm{mmol} / \mathrm{l}$ non-essential amino acids $\times 100,23.8 \mathrm{mmol} / \mathrm{l} \mathrm{NaHCO}_{3}, 10 \mathrm{mmol} / \mathrm{H} \mathrm{HEPE} \mathrm{(all} \mathrm{from}$ $\mathrm{G}$ ibco, Heidelberg, Germany) and $10 \%$ heat inactivated fetal calf serum (FCS) (Boehringer $M$ annheim, M annheim, Germany).

A nimals. M ale Wistar rats (weight $200 \mathrm{~g}$ ) from the $\mathrm{U}$ niversity breeding facility received a standard diet ("Sniff-R"; Sniff, Soest, G ermany) and tap water ad libitum.

I solation of cells. IE C were isolated by outgrowth from isolated rat pancreatic islets as described [6]. B riefly, pancreatic islets were harvested by ductual injection of collagenase, submitted to gradient centrifugation and hand picked. Freshly isolated whole islets were cultured in RPM I 1640/10\% FCS supplemented with $100 \mu \mathrm{g} \mathrm{ECGS/ml} \mathrm{for} \mathrm{6-8} \mathrm{days,} \mathrm{respectively,} \mathrm{de-}$ pending on the degree of endothelial cell outgrowth. Islets were then removed, IEC detached by trypsin treatment, placed onto plastic culture dishes in RPMI/FCS and subcultured. Characterization of IE C was performed using specific endothelial markers as described [6]. R emoval from culture dishes for each passage was performed by treatment with $0.05 \%$ trypsin $/ 0.02 \%$ EDTA in isotonic $\mathrm{NaCl}$ for about $3 \mathrm{~min}$. A fter the second passage, the cells were frozen in $\mathrm{RPMI} / \mathrm{FCS} / 10 \% \mathrm{DMSO}$ at $-80^{\circ} \mathrm{C}$ until use. I slet cells were obtained from isolated islets after dissociation into single-cell suspensions exactly as described previously [15]. Subsequently, the islet cells were purified from non-endocrine cells by an adherence step in culture dishes for $18 \mathrm{~h}$.

Co-culture of endothelial and islet cells and quantification of cell lysis. O nly IE C of passage 4-6 were used for the co-culture experiments. Cells were cultured in 48 multiwell tissue culture plates (Becton Dickinson, Lincoln Park, NY USA) to a density of about $9 \times 10^{4}$ cells/well and activated with a mixture of $500 \mathrm{U} / \mathrm{ml} \mathrm{IL}-1 \beta, 300 \mathrm{U} / \mathrm{ml} \mathrm{TNF}-\alpha$ and $100 \mathrm{U} / \mathrm{ml}$ gamma-IFN . A fter a challenge for $24 \mathrm{~h}$, the IE C were washed three times with fresh medium to remove the cytokines. I solated islet cells, purified by overnight adherence, were then added at various amounts to achieve the appropriate target : effector cell ratios. A t the end of the co-culture, cell lysis was determined by trypan blue exclusion. For each well, $2 \times 10^{2}$ islet cells or more were counted. I slet cells could easily be distinguished from the elongated and tightly adherent endothelial cells. For electron microscopy preparations IE C were cultured in permanox eight-well tissue culture chambers (Nunc, Naperville, IL U SA ) under conditions exactly as above. To avoid loss of cells due to transfer steps during fixation, dehydration and embedding, all steps were performed in the permanox chambers. B riefly, the cells were fixed with $2 \%$ glutaraldehyde in $0.1 \mathrm{~mol} / \mathrm{l}$ cacodylate- $\mathrm{H} \mathrm{Cl}$ buffer for $15 \mathrm{~min}$ and postfixed with $1.5 \% \mathrm{O} \mathrm{sO}_{4}$ for $40 \mathrm{~min}$ at $4^{\circ} \mathrm{C}$. Specimens were dehydrated in a graded ethanol series and embedded in a thin layer of Spurr's epoxy resin. A fter polymerization, the epoxy layer containing the cells was removed from the plastic support and embedded in a manner oriented to allow relocation of cells in ultrathin sections. Specimens were analysed in a coded fashion. From each preparation more than $2 \times 10^{2}$ islet cells were analysed by transmission electron microscopy from 4-5 ultrathin sections cut from different planes of the cell layers. Cell viability was judged from electron density of cytoplasm together with preservation of intact structures of cellular organelles and continuity of cell membrane. Beta and nonbeta cells were distinguished by secretory granule morphology.

D etermination of DNA strand breaks. For recognition of D NA strand breaks at single cell level, the method of in situ nicktranslation was performed as described [16]. Briefly, co-cultures were dried on the slides and fixed in acetone. Endogenous peroxidase activity was inhibited by incubation with $0.3 \% \mathrm{H}_{2} \mathrm{O}_{2}$ in methanol for $30 \mathrm{~min}$. The nick-translation reaction was performed for $15 \mathrm{~min}$ at room temperature in $50 \mathrm{mmol} / \mathrm{l}$ Tris- $\mathrm{H} \mathrm{Cl}, \mathrm{pH} 7.5$, containing $3 \mu \mathrm{mol} / \mathrm{l}$ biotin-dU TP, $5 \mathrm{U} / 100 \mu \mathrm{l}$ Kornberg polymerase, $3 \mu \mathrm{mol} / \mathrm{l}$ each of dGTP, $\mathrm{dCTP}$, and $\mathrm{dATP}$ and $0.1 \mathrm{mmol} / \mathrm{l}$ dithiothreitol (all components from B oehringer $M$ annheim). The slides were then washed three times in phosphate buffered saline (PBS) and processed for immunocytochemical detection of biotin. U nspecific antibody binding was blocked by preincubation with PBS containing $0.1 \%$ thimerosal and $10 \% \mathrm{FCS}$ for $10 \mathrm{~min}$. The incorporated biotin-dUTP was visualized by the peroxidase reaction (Vectastain kit; Camon, Wiesbaden, G ermany) using diaminobenzidine as substrate. Stained cells were determined by counting more than $3 \times 10^{2}$ isl et cells in at least two different wells.

D etermination of nitrite concentrations. $\mathrm{N}$ itrite concentrations were determined by diazotization reaction performed in Pro$B$ ind assay plates (Becton Dickinson). Culture supernatants $(100 \mu \mathrm{l})$ were mixed with $50 \mu \mathrm{l} 1 \%$ (w/v) sulphanilamide dissolved in $2.5 \% \mathrm{H}_{3} \mathrm{PO}_{4}$. A fter $5 \mathrm{~min}, 50 \mu \mathrm{l} 0.3 \%$ (w/v) naphtylethylendiamine dissolved in $2.5 \% \quad \mathrm{H}_{3} \mathrm{PO}_{4}$ was added. A fter adding $20 \mu \mathrm{l}$ methanol to remove air bubbles, the absorbance at $540 \mathrm{~nm}$ was measured in a microplate reader using culture medium incubated without cells as a blank and $\mathrm{NaNO}_{2}$ as a standard.

\section{Statistical analysis}

$D$ ata are given as arithmetical means \pm SD . $p$-values were calculated using analysis with Student's t-test (two-tailed for independent samples). 


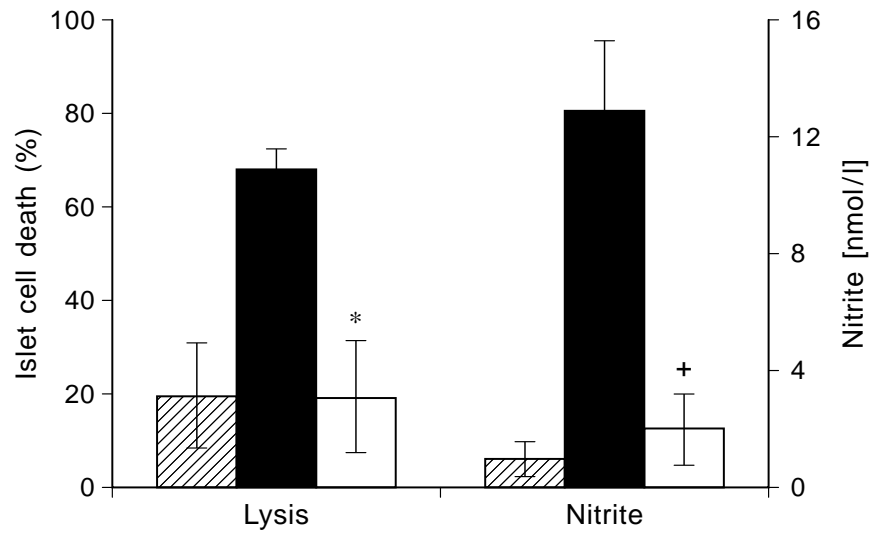

Fig. 1. Lysis of islet cells by islet endothelial cells (IE C). I solated islet cells were co-cultured with resident (ख्य) or preactivated IE C at a target : effector cell ratio of $1: 3$ in the absence ( $\square$ ) or presence $(\square)$ of $0.5 \mathrm{mmol} / / \mathrm{NM} \mathrm{A}$. A fter $24 \mathrm{~h}$, islet cell lysis was determined by trypan blue exclusion and nitrite concentrations were determined in the culture supernatants. Values are means \pm SD of 3-4 individual experiments. $p$-values compare pre-activated IEC with pre-activated IEC + NMA. $* p<0.007 ;+p<0.0001$

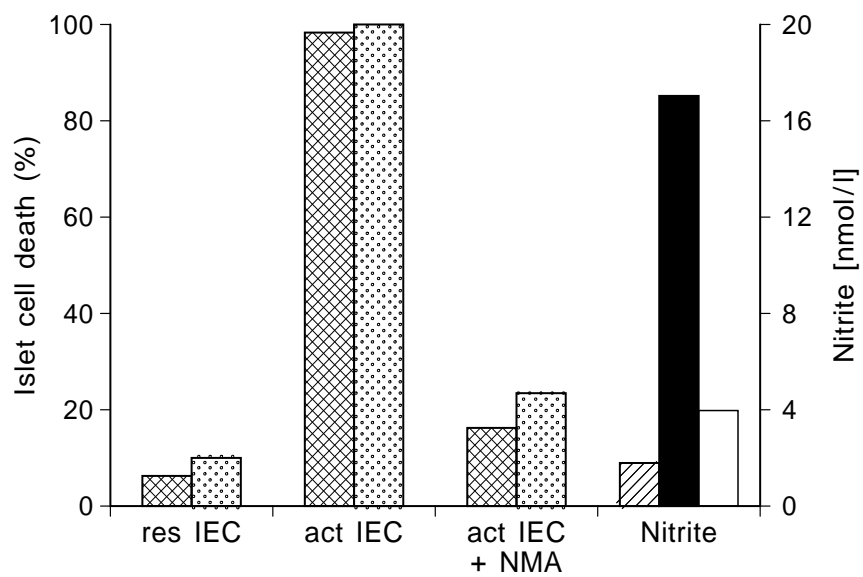

Fig. 2. Lysis of beta and non-beta cells by IEC as determined by electron microscopy. I solated islet cells were co-cultured with resident (res) or pre-activated (act) IE C at a target : effector cell ratio of $1: 1$ in the absence or presence of $0.5 \mathrm{mmol} / \mathrm{l}$ NM A . A fter $24 \mathrm{~h}$, cultures were processed for electron microscopy. For each specimen $2 \times 10^{2}$ or more islet cells were examined (beta cells, non-beta cells, $\square$ ). Nitrite concentrations in the coculture supernatants with resident (ख्A) or pre-activated IE C in the absence ( $\square$ ) or presence $(\square)$ of $0.5 \mathrm{mmol} / \mathrm{l}$ N M A were determined. R esults of two experiments are shown

Results

$\mathrm{R}$ at IE C layers were pre-activated by the addition of

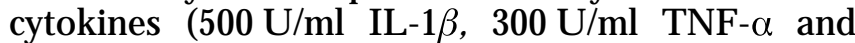
$100 \mathrm{U} / \mathrm{ml}$ gamma-IFN) which were removed by extensive washing prior to the co-culture with isolated islet cells. A fter various periods of time, islet cell lysis was monitored by trypan blue exclusion. A t a target : effector cell ratio of $1: 3$, cytokine pre-activated IE C were found to lyse islet cells within 24 h (67.5 \pm
$4.2 \%, n=4$; Fig. 1). I slet cells were protected from endothelium-mediated lysis when cultured in the presence of $0.5 \mathrm{mmol} / \mathrm{l} \mathrm{NMA}$. Protection was complete, i. e. observed islet death was identical to co-cultures with resident IE C $(19.3 \pm 11.9$ vs $19.6 \pm 11.1 \%)$. Lysis correlated with the concentrations of the stable $\mathrm{NO}$ oxidation product nitrite found in the co-culture supernatants: after co-culture with pre-activated IE C high concentrations of nitrite $(12.4 \pm 2.4 \mathrm{nmol} / \mathrm{l})$ could be measured, whereas in co-cultures with resident IEC or with activated IEC in the presence of NMA, respectively, only low nitrite concentrations were found ( $1.0 \pm 0.6$ vs $2.0 \pm 1.2 \mathrm{nmol} / \mathrm{l} ; \mathrm{Fig} .1)$. Culture of $3 \times 10^{4}$ purified islet cells in the absence or presence of the cytokine-mixture for $24 \mathrm{~h}$ resulted in the production of $2.0 \pm 0.1$ or $1.1 \pm 0.5(n=6) \mathrm{nmol} / \mathrm{l}$ of nitrite. This is comparable to the value of $65 \mathrm{pmol}$ nitrite per $2 \times 10^{3}$ fluorescence activated cell sorter (FA CS) purified beta cells measured after incubation with IL $-1 \beta$ for $18 \mathrm{~h}$ as found by others [17]. Culture of islet cells for $24 \mathrm{~h}$ in the presence of the cytokine-mixture did not lead to increased lysis $(10.6 \pm 4.7$ vs $8.9 \pm 5.3 \%$ lysis in the absence of cytokines, $n=4$ ). Culture of cytokine-activated IE C in the presence or absence of islet cells did not significantly change the nitrite values found in the respective supernatants (data not shown).

To determine whether IE C-mediated islet cell lysis is beta cell-specific, we analysed co-cultures by electron microscopy. For the sake of quantification, these co-culture experiments were performed at a target : effector cell ratio of $1: 1$ under otherwise identical conditions. Culturing isolated islet cells with resident IEC or with pre-activated IEC in the presence of $0.5 \mathrm{mmol} / \mathrm{l} \mathrm{NMA}$ resulted in the formation of small aggregates of intact islet cells (pseudo islets) strongly adherent to the IE C containing both beta and non-beta cells. In contrast, co-culture with pre-activated IEC led to complete lysis of both islet beta and islet non-beta cells after $24 \mathrm{~h}$ (Fig. 2) yielding single islet cells with all morphological aspects of lysis and no evidence for an apoptotic cell death (Fig. 3A ). Both beta and non-beta cells were protected from lysis by addition of $0.5 \mathrm{mmol} / \mathrm{N} \mathrm{NMA}$ to values similar to control co-cultures with resident IEC.

To determine whether islet cell death induced by cytokine-activated IEC is preceded by DNA strand breaks as previously described for islet cell killing by activated macrophages [18], we also performed in situ nick-translation assays in these co-cultures. Indeed, DNA strand breaks were detected in $47.6 \pm 7.3 \%(n=3)$ of islet cell nuclei $8 \mathrm{~h}$ after coculture with activated IEC (Fig.4B). In contrast, when islet cells were co-cultured with resident IEC (Fig. 4A), DNA strand breaks were a rare event $(7.0 \pm 2.4 \% ; n=3)$. IEC never showed any DNA strand breaks. 


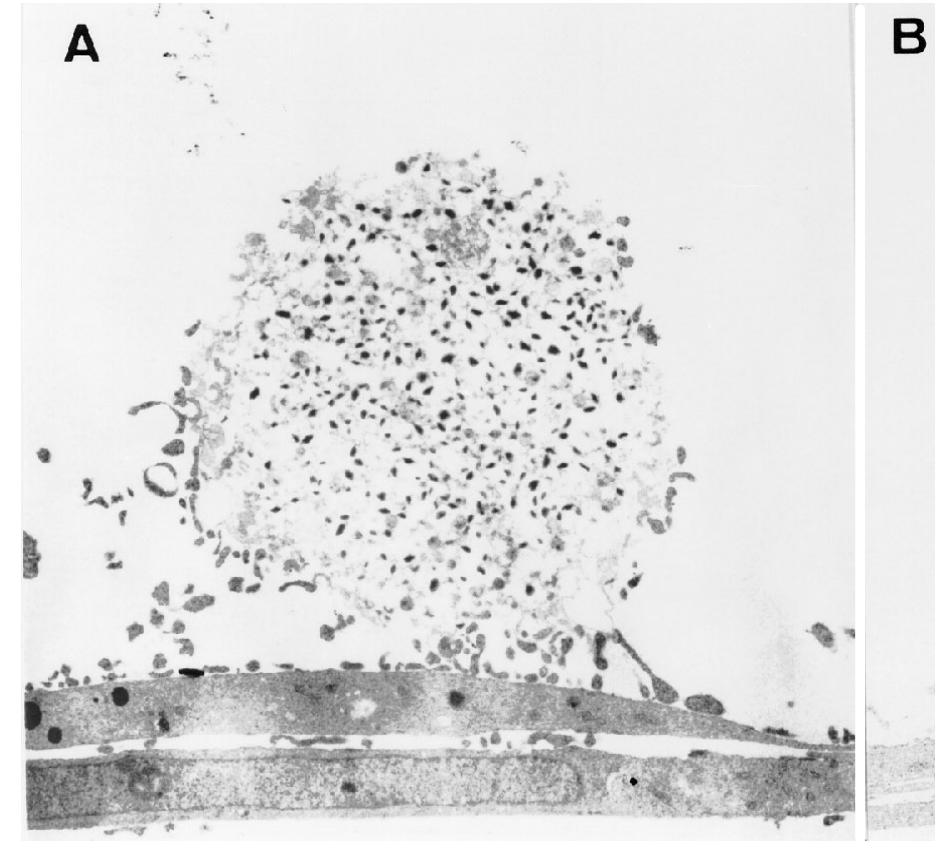

B

Fig. 3. (A, B ) Electron micrographs of islet cells co-cultured with IE C. I solated islet cells were cultured with pre-activated IEC at a target : effector cell ratio of $1: 1$ in the absence $(\mathbf{A})$ or presence of $0.5 \mathrm{mmol} / \mathrm{INMA}$ (B) for $24 \mathrm{~h}$ and were then processed for electron microscopy. I slet cell lysis is evident in cultures with pre-activated IEC as recognized by plasma membrane disruption and loss of cytoplasmic content among other features (A) . In contrast, co-cultures with pre-activated E C in the presence of NMA resulted in normal islet cell morphology and the formation of small reassociated cell aggregates (B) with contact zones to the IE C exactly as found in co-cultures with resident IEC. M agnification A , ×5600; B , ×4000

\section{Discussion}

In animal models IDDM develops in the absence of M H C class I-restricted cytotoxicity, suggesting a contribution to tissue destruction by unspecific effector cells, e.g. macrophages and others [19]. There is increasing evidence from studies in animal models that iNOS expression in inflamed islets contributes to the destruction of islet cells via generation of high local concentrations of $\mathrm{NO}$ in addition to local production of oxygen radicals and pro-inflammatory cytokines.

$R$ at islets are highly capillarized $[20,21]$ with 8 to 10 beta cells forming a tube-like structure around a central capillary so that each beta cell faces two capilIaries [22]. Thus, each beta cell within an islet is in proximity to two IEC. EC from larger vessels have been shown to be activated by cytokines to express iN OS and to produce large amounts of NO $[4,5]$. R ecently we demonstrated that this holds true for pure cultures of islet capillary EC as well [6]. Thus, activated endothelia in islets could theoretically become effector cells present in the inflammatory surrounding of infiltrated islets.

To test this hypothesis, we performed co-culture experiments. We found, that upon cytokine challenge IE C at the low target : effector cell ratios of $1: 3$ to $1: 1$ mediated strong to complete lysis of syngeneic islet cells via NO yielding single lysed islet cells still mostly in contact with the endothelial layer. With resident or NMA-treated activated IEC, islet cells formed small pseudo-islets and showed strong adherence of both beta and non-beta cells to IEC with broad contact zones suggesting the involvement of a specific adhesion mechanism. Pre-activated IEC were found to lyse both beta and non-beta cells, a result identical to previous data obtained for islet cell killing by activated macrophages [23]. L ikewise, lysis of islet cells was preceded by DNA strand breaks with no morphological evidence of apoptosis identical to previous findings with activated macrophages [18] and NO donors [18, 24].

A ctivated EC are known to secrete cytokines such as IL-1 $\beta, \mathrm{IL}-6$ and IL-8 [1]. However, a previous study had shown that lysis of islet cells by activated macrophages was not inhibited or influenced by neutralizing antibodies specific for IL $-1 \beta$ or TNF- $\alpha$ [14]. Furthermore, the cytokine mixture used to pre-activate the IEC was not cytotoxic for the islet cells. A Ithough IL $-1 \beta$ may severely impair cellular functions of islet cells [25], lysis of isolated islet cells due to incubation with $\mathrm{IL}-1 \beta$ has not been demonstrated $[26,27]$ in contrast to lysis in whole islets $[28,29]$, suggesting the need of non-endocrine islet cells for IL$1 \beta$-mediated cytotoxicity. The combination of IL-1, TNF- $\alpha$ and gamma-IFN has been found to mediate partial cytotoxicity towards isolated islet cells but only after many days of culture [30, 31]. 


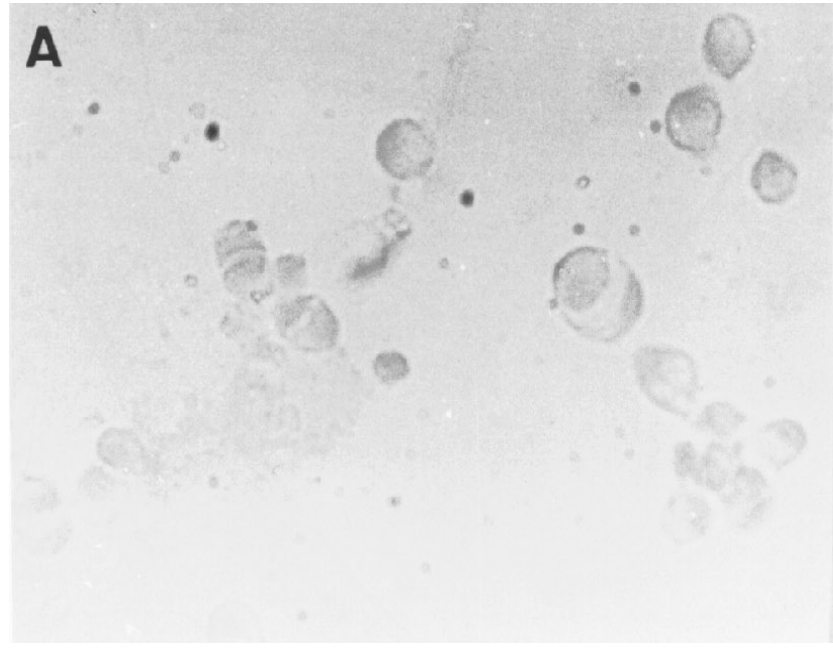

Fig. 4. (A , B ) D etection of D N A strand breaks after co-culture with IEC. I solated islet cells were co-cultured with resident (A) or pre-activated IE C (B) at a target : effector cell ratio of $1: 3$. A fter $8 \mathrm{~h}$, cells were fixed and D NA strand breaks were detected by in situ nick translation. M icrographs were focussed to the plane of adhering islet cells with the endothelial layer below the foucs and only seen as a vague shadow, as $E$ C nuclei did not stain. In contrast, islet cell nuclei show intense dark staining after co-culture with pre-activated IE C (B). Magnification $\times 560$

In conclusion, we describe here for the first time that activated tissue-specific E C are able to lyse syngeneic mammalian target cells and to mediate DNA damage. IE C thus can actively participate in islet destruction and may thus be relevant effector cells in early stages of IDDM development as well as other inflammatory diseases.

A cknowledgements. We thank Ms. U.Lammersen and M S. C.Wilkens for the excellent technical assistance and $\mathrm{MS}$. S. Wenzel and MS. M.Turken for processing of the photographs.

\section{References}

1. M ontavani A , B ussolino F, D ejana E (1992) Cytokine regulation of endothelial cell function. FA SE B J. 6: 2591-2599

2. M utsubara T, Ziff M (1986) Increased superoxide anion release from human endothelial cells in response to cytokines. J I mmunol 137: 3295-3298

3. M urphy H, Shayman J S, Till G O et al. (1992) Superoxide responses of endothelial cells to $C 5$ a and TNF- $\alpha$ : divergent signal transduction pathways. A m J Physiol 263: L 51-L 59

4. Kilbourn R G, Belloni P (1990) E ndothelial cell production of nitrogen oxides in response to interferon $\gamma$ in combination with tumor necrosis factor, interleukin-1, or endotoxin. J Natl Cancer Inst 82: 772-776

5. Suschek C, R othe H, Fehsel K, Enczmann J, Kolb-B achofen $V$ (1993) Induction of macrophage-like nitric oxide synthase in cultured rat aortic endothelial cells. J Immunol 151: 3283-3291

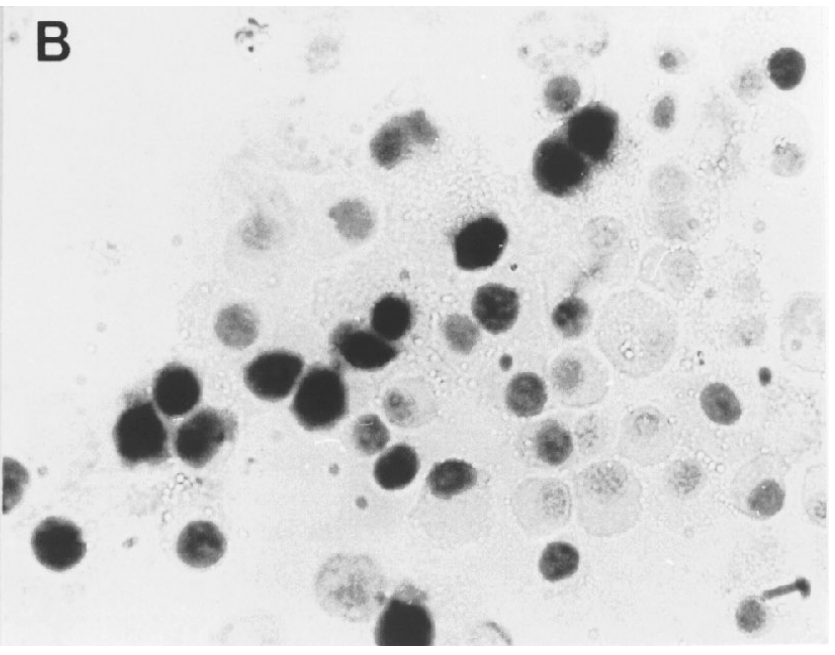

6. Suschek C, Fehsel K, K röncke KD, Sommer A, KolbBachofen V (1994) Primary cultures of rat islet capillary endothelial cells. Constitutive and cytokine-inducible macrophagelike nitric oxide synthases are expressed and activities regulated by glucose concentration. A m J Pathol 145: 685-695

7. L ukic M L, Stosic-G rujicic S, O stojic N, Chan WL, L iew FY (1991) Inhibition of nitric oxide generation affects the induction of diabetes by streptozotocin in mice. Biochem B iophys R es Commun 178: 913-920

8. Kolb H, Kiesel U, K röncke KD, Kolb-Bachofen V (1991) Suppression of low dose streptozotocin induced diabetes in mice by administration of nitric oxide synthase inhibitor. L ife Sci 49: PL 213-PL 217

9. Lindsay MR, Smith W, Rossiter SR, Mcl ntyre MA, Williams B C, B aird J D (1995) NW-nitro-L-arginine methyl ester reduces the incidence of IDDM in $B B / E$ rats. Diabetes 44: $365-368$

10. Wu G (1995) Nitric oxide synthesis and the effect of aminoguanidine and $N^{G}$-monomethyl-L-arginine on the onset of diabetes in the spontaneously diabetic BB rat. Diabetes 44: $360-364$

11. Kolb-B achofen V, E pstein S, K iesel U, Kolb H (1988) L ow dose streptozotocin-induced diabetes in mice. Electron microscopy reveals single-cell insulitis before diabetes onset. D iabetes 37: 21-27

12. Lee $K U, K$ im $M K$, A mano $K$, Pak $C Y$, Jaworski $M A$, M ehta J G, Y oon J W (1988) Preferential infiltration of macrophages during early stages of insulitis in diabetes-prone B B rats. Diabetes 37: 1053-1058

13. $\mathrm{H}$ anenberg $\mathrm{H}$, Kolb-B achofen $\mathrm{V}$, K antwerk-F unke $\mathrm{G}$, Kolb $H$ (1989) M acrophage infiltration precedes and is prerequisite for lymphocytic insulitis of pre-diabetic BB rats. Diabetologia 32: 126-134

14. K röncke $K D$, Kolb-B achofen $V$, B erschick B, B urkart $V$, Kolb H (1991) A ctivated macrophages kill pancreatic syngeneic islet cells via arginine-dependent nitric oxide generation. B iochem Biophys R es Commun 175: 752-758

15. K röncke K D, Funda J, B erschik B, K olb H , Kolb-B achofen V (1991) M acrophage cytotoxicity towards isolated islet cells: neither lysis nor its protection by nicotinamide are beta-cell specific. D iabetologia 34: 232-238

16. Fehsel K, Kolb-Bachofen V, Kolb H (1991) A nalysis of TNF- $\alpha$-induced DNA strand breaks at the single cell level. A m J Pathol 139: 251-254

17. Corbett JA, MCD aniel ML (1995) Intraislet release of interleukin 1 inhibits $\beta$ cell function by inducing $\beta$ cell 
expression of inducible nitric oxide synthase. J Exp M ed 181: 559-568

18. Fehsel K, Jalowy A, Q i S, B urkart V, Hartmann B, Kolb H (1993) Islet cell D N A is a target of inflammatory attack by nitric oxide. $D$ iabetes 42: 496-500

19. Kolb H, Kolb-Bachofen V, R oep BO (1995) A utoimmune versus inflammatory type I diabetes: a controversy? Immunol Today 16: 170-172

20. Vetterlein V, Petho A , Schmidt G (1987) M orphometric investigation of the microvascular system of pancreatic exocrine and endocrine tissue in the rat. M icrovasc Res 34: 231-238

21. Svensson A M, Jansson L, H ellerström C (1988) The volume and area of the capillaries in the endocrine and exocrine pancreas of the rat. $\mathrm{H}$ istochemistry 90: 43-46

22. B onner-W eir S (1988) M orphological evidence for pancreatic polarity of $\beta$-cell within islets of $L$ angerhans. D iabetes 37: 616-621

23. K röncke $K D$, R odriguez $M L$, Kolb $H$, Kolb-B achofen $V$ (1993) Cytotoxicity of activated macrophages against syngeneic islet cells is arginine-dependent, correlates with citrulline and nitrite concentrations and is identical to lysis by the nitric oxide donor nitroprusside. Diabetologia 36: $17-24$

24. Kröncke KD, Brenner HH, Rodriguez ML et al. (1993) Pancreatic islet cells are highly susceptible towards the cytotoxic effects of chemically generated nitric oxide. Biochem B iophys A cta 1182: 221-229
25. M andrup-Poulsen T (1996) The role of interleukin-1 in the pathogenesis of ID D M. Diabetologia 39: 1005-1029

26. Ling Z, Int't Veld PA, Pipeleers D G (1993) Interaction of interleukin- 1 with islet $\beta$-cells; distinction between indirect, aspecific cytotoxicity and direct, specific functional suppression. Diabetes 42: 56-65

27. K röncke KD, Fehsel K, Kleemann R, Kolb-Bachofen V, Kolb H (1994) R ole of nitric oxide in the development of insulin-dependent diabetes. In: Flatt PR, L enzen S (eds) Insulin secretion and pancreatic B-cell research. Smith G ordon and Co., London, pp 575-579

28. $M$ andrup-Poulsen $T, B$ endtzen $K, N$ erup J, Dinarello $C A$, Svenson M, Nielsen J H (1986) A ffinity-purified human interleukin 1 is cytotoxic to isolated islets of Langerhans. Diabetologia 29: 63-67

29. Bergmann L, K röncke KD, Suschek $C, K$ olb $H$, Kolb$B$ achofen V (1992) Cytotoxic action of IL-1 $\beta$ against pancreatic islets is mediated via nitric oxide formation and is inhibited by $N^{G}$-monomethyl-L-arginine. FEBS Lett 299: 103-106

30. Pukel C, B aquerizo H, Rabinovitch A (1988) D estruction of rat islet cell monolayers by cytokines; synergistic interactions of interferon-gamma, tumor necrosis factor, lymphotoxin, and interleukin 1. Diabetes 37: 133-136

31. Rabinovitch A, Sumoski W, Rajotte RV, Warnock GL (1990) Cytotoxic effects of cytokines on human pancreatic islet cells in monolayer culture. J Clin E ndocrinol M etabol 71: 152-156 